\title{
Evaluation of Complete Blood Count Parameters Before and After Appendectomy
}

\author{
Durak Katipoğlu1 1 (D) Togay Evrin 1 , (D) Ayhan Sümer Yaman²
}

1 Ufuk University Faculty of Medicine, Department of Emergency Medicine, Ankara, Turkey

${ }^{2}$ Ankara Training and Research Center, Clinic of Emergency Medicine, Ankara, Turkey

\section{Abstract}

Objective: Acute appendicitis (AA) is the most common cause of intra-abdominal surgery worldwide and its diagnosis continues to be problematic despite advanced technology and diagnostic methods. Easily accessible, economical and non-invasive tests are still under investigation for the diagnosis and after surgery. The purpose of this study was to review postoperative changes in patients' complete blood count (CBC) parameters.

Methods: The research was performed as a single-center, retrospective, cross-sectional study. After obtaining the approval of the ethics committee, the data obtained from patients aged over 18, who underwent appendectomy between January 1, 2015 and November 30, 2017, and who were diagnosed with histopathologically confirmed AA, were retrospectively examined. Wilcoxon test was used in statistical analysis to compare pre- and post-operative changes in CBC parameters. A p value of less than 0.05 was considered statistically significant.

Results: Men constituted 50\% ( $\mathrm{n}=726$ ) of the 1452 enrolled patients. The mean age of the patients was $32.3 \pm 16.1$ years. Statistically significant differences were determined between pre-operative and post-operative leukocyte white blood cell, lymphocyte, hemoglobin, hematocrit, plateletcrit and mean platelet volume values. Mean neutrophil and platelet count values decreased in the post-operative period, although these decreases were not statistically significant. No statistically significant difference was determined between pre-operative and post-operative neutrophil/lymphocyte ratio (NLR) values.

Conclusion: Dilutional changes in CBC parameters may occur following fluid therapy in the post-operative period. We also conclude that NLR is not affected by fluid treatment and may be a valuable parameter in monitoring post-appendectomy infection.

Keywords: Acute appendicitis, blood count, neutrophil/leukocyte ratio, mean platelet volume, platelet count

\section{INTRODUCTION}

Acute appendicitis (AA) ranks first among intra-abdominal pathologies requiring surgery (1). Mortality and morbidity are low if surgery is performed early (2). Typical AA findings include right lower quadrant tenderness, anorexia, nausea, pain migration and rebound positivity on physical examination (3). The presence of atypical findings depending on the location of the appendix may cause AA to be missed and complications may develop. Some patients diagnosed with AA may present to emergency departments with non-specific symptoms or additional symptoms of other diseases. AA cases presenting with right upper quadrant pain or anuria alone have also been reported. AA has also been reported in patients presenting with findings such as psoas abscess in the gluteal region or cellulitis
(4-6). Therefore, post-operative parameters are needed for use in the clinical follow-up of AA patients. Blood tests such as leukocyte count white blood cell (WBC), neutrophil/lymphocyte ratio (NLR) and C-reactive protein (CRP) are used in addition to abdominal ultrasonography in the diagnosis of AA, but these may not always be sufficient for a definitive diagnosis. In this case, intravenous contrast-enhanced abdominal computed tomography is recommended $(3,7,8)$. Recent studies have shown that platelet markers such as mean platelet volume (MPV), platelet distribution width (PDW) and platelet count are useful in the diagnosis of AA. Platelet activation markers such as plateletcrit (PCT), MPV and PDW are associated with platelet morphology and proliferation kinetics. These markers permit low-cost focusing on diagnostic and prognostic values and broad clinical investigation $(9,10)$. The aim of this study was to 
assess whether the regression of preexisting infection before appendectomy could be determined by evaluating complete blood count (CBC) parameters after appendectomy.

\section{METHODS}

This research was performed as a single-center, retrospective, cross sectional study. After receiving the approval of the local ethics committee of Ankara Training and Research Hospital (approval no: 13122017/0028.311), the data obtained from patients aged over 18, who underwent appendectomy between January 1, 2015 and November 30, 2017, and who were diagnosed with histopathologically confirmed AA, were retrospectively examined hospital records. Pregnant subjects and patients with liver or kidney failure, malignancy or known hematological disease, patients under 18 of age and patients with missing data were excluded from the study.

\section{Statistical Analysis}

Statistical Package for the Social Sciences (SPSS) 15.0 for Windows was used for statistical analysis. Visual (histogram, probability, and plot) and analytical methods (Kolmogorov-Smirnov/ShapiroWilk tests) were used to assess whether the variables were normally distributed. Descriptive analyses were expressed using median and 25-75 percentiles. Since blood count parameters were not normally distributed, non-parametric tests were used to compare them, similar to gradient variables. Wilcoxon test was used to compare changes in pre-operative and post-operative blood count parameters. A p value less than 0.05 was considered statistically significant.

\section{RESULTS}

We identified 1837 patients who underwent appendectomy between January 1, 2015 and November 30, 2017 with histopathologically confirmed AA. Patient data was examined using the automation information processing data. One hundred and eighty-five patients were excluded due to missing data in 77 patients, malignancy or hematological diseases in 44 patients, being under 18 years in 38 patients, liver or kidney failure in 19 patients, and pregnancy in seven patients. Therefore, 1452 patients were eventually enrolled. Seven hundred and twentysix (50\%) patients were female and $726(50 \%)$ were male, with a mean age of $32.3 \pm 16.1$ years (range, 18-43 years). There was no statistically significant between the genders in terms of age $(p>0.05)$. The mean pre-operative CBC parameters were as follows: WBC count $=10.200 / \mathrm{mm}^{3}$ (range, 39.800-10.200/ $\mathrm{mm}^{3}$ ), lymphocyte count $=2000 / \mathrm{mm}^{3}$ (range, 1320-3570/ $\mathrm{mm}^{3}$ ), neutrophil count $=5500 / \mathrm{mm}^{3}$ (range, $\left.1780-5380 / \mathrm{mm}^{3}\right)$, hemoglobin $(\mathrm{Hb})=14.1 \mathrm{~g} / \mathrm{dL}$ (range, 14.1-18.1 g/dL), hematocrit $(\mathrm{Hct})=41.2 \%$ (range, 43.5-53.7\%), NLR=2.24, PCT $=0.23 \%$ (range, $0.15 \%-0.7 \%$ ), PDW=12.00 fL (range, 9-19 fL), MPV=8.60 fL (range, 6.8-10.8 fL) and mean platelet count $=248.000 / \mathrm{mm}^{3}$ (range, $\left.142.000-424.000 / \mathrm{mm}^{3}\right)$.

The mean post-operative CBC parameters were as follows: WBC count $=7600 / \mathrm{mm}^{3}$, lymphocyte count $=1900 / \mathrm{mm}^{3}$, neutrophil count $=4900 / \mathrm{mm}^{3}, \quad \mathrm{Hb}=13.6 \mathrm{~g} / \mathrm{dL}, \quad \mathrm{Hct}=41.4 \%, \quad \mathrm{NLR}=2.37$, $\mathrm{PCT}=0.19 \%, \mathrm{PDW}=11.70 \mathrm{fL}, \mathrm{MPV}=8.00 \mathrm{fL}$ and platelet count $=241.000 / \mathrm{mm}^{3}$. The mean pre-operative WBC, lymphocyte, $\mathrm{Hb}$, Hct, PCT and MPV values were significantly higher than postoperative values $(p<0.001)$. A statistically insignificant decrease was observed in postoperative mean neutrophil, PDW and platelet count compared to pre-operative levels $(p>0.05)$. There was no statistically significant difference between pre-operative and post-operative NLR values ( $p>0.05)$. Mean pre-operative and post-operative blood count parameters are shown in Table 1.

\section{DISCUSSION}

All platelet parameters such as PDW, MPV, PCT and platelet counts decreased between pre- and post-operative values. However, only the decreases in PCT and MPV values were statistically significant.

AA is the most common cause of intra-abdominal surgery. It is also one of the most common reasons for admissions to the emergency department, and the search for a rapid and easily performed test for the diagnosis of AA continues. Contemporary

Table 1. Mean complete blood count parameters in preoperative and post-operative periods

\begin{tabular}{|l|l|l|l|}
\hline & $\begin{array}{l}\text { Pre- } \\
\text { operative }\end{array}$ & Post-operative & $\mathbf{p}$ \\
\hline White blood cell (/mm³) & 10.20 & 7.60 & $<0.001$ \\
\hline Lymphocyte $\left(/ \mathrm{mm}^{3}\right)$ & 2.00 & 1.90 & $<0.001$ \\
\hline Neutrophil (/mm3) & 5.50 & 4.90 & 0.035 \\
\hline $\begin{array}{l}\text { Neutrophil/lymphocyte } \\
\text { ratio }\end{array}$ & 2.24 & 2.37 & 0.228 \\
\hline Hematocrit (\%) & 41.20 & 41.40 & $<0.001$ \\
\hline $\begin{array}{l}\text { Hemoglobin (g/dL) } \\
\text { Platelet (/mm })\end{array}$ & 14.10 & 13.60 & $<0.001$ \\
\hline Plateletcrit (\%) & 248.000 & 241.000 & 0.612 \\
\hline $\begin{array}{l}\text { Platelet distribution } \\
\text { width (fL) }\end{array}$ & 12.00 & 0.19 & $<0.001$ \\
\hline $\begin{array}{l}\text { Mean platelet volume } \\
\text { (fL) }\end{array}$ & 8.60 & 8.00 & 0.200 \\
\hline & & \multicolumn{2}{|l}{} \\
\hline
\end{tabular}


studies have shown that platelet markers such as MPV, PDW and PCT can be used both in diagnosis and in predicting the prognosis of AA (11-13). However, the results of platelet markers in the diagnosis of AA are inconsistent. In a study of 503 subjects, Narci et al. (14) concluded that MPV values increased in AA patients. In contrast, in a study conducted in 2015, Kılıç et al. (15) reported a statistically significant decrease in MPV values in AA patients. There are other studies supporting this conclusion $(11,16,17)$. In contrast to both studies, other studies with larger patient groups reported no changes in MPV values $(13,18,19)$. In a study of 295 patients in 2015, Uyanik et al. (20) reported a statistically significant decrease in MPV values together with a decrease in PDW. In contrast, Fan et al. (17) reported a statistically significant increase in PDW values and a statistically significant increase in MPV values in AA patients. In contrast to several previous studies, our findings indicate that platelet markers such as PDW, PCT and $M P V$ are not useful in the diagnosis of AA and in predicting its severity, since they exhibit a hemodilutional decrease related to hydration therapy. Since no information was available regarding whether our patients were complicated or uncomplicated in the pre-operative period, the antibiotic use status of the patients is unknown. Based on mean post-operative data, WBC, neutrophil and lymphocyte counts decreased. This can be attributed to hemodilution as well as AA being an infection that heals in the post-operative period. Therefore, it is not surprising that a decrease should be observed in leukocytes, which are one of the strongest markers of infection. Since a decrease was observed in all CBC parameters (including $\mathrm{Hb}$, Hct, platelets and lymphocytes), we concluded that these values tended to decrease secondary to hemodilution. Normovolemic hemodilution with crystalloid or colloid solutions based on a calculation of blood loss during surgery is a method that has been applied for many years $(21,22)$. A relative decrease in blood cell components due to a hemodilution-related increase in blood plasma volume is not surprising. Our study results seem to be compatible with hemodilution. Under these circumstances, it would not therefore be right to expect an increase in $\mathrm{CBC}$ parameters of WBC or neutrophil count alone. Since the patient's blood parameters decrease with hemodilution in the post-operative period, they will appear decreased or normal after the test, even if the WBC count increases in association with infection. A hemodilutionrelated decrease occurs in both neutrophil and lymphocyte counts. However, this decrease did not cause a statistically significant decrease in NLR. Therefore, we concluded that the NLR was not affected by hemodilution.

In recent years, NLR has been regarded as more effective than WBC or CRP alone in determining or following-up infection $(7,23,24)$. Our results support the idea that NRL is more valuable than WBC or neutrophil counts in monitoring infections since it is not affected by hemodilution.

\section{Study Limitations}

Due to the retrospective nature of our study, our inability to access data for several patients resulted in a decrease in the number of patients. One of the main limitations of this study is that patients taken for appendectomy were not classified according to severity of the disease in the pre-operative period or according to the development of complications. Another limitation was that CRP values were not examined postoperatively while $\mathrm{CBC}$ values were investigated. Correlation analysis between changes in CRP values and blood count values may represent the subject of another study.

\section{CONCLUSION}

The blood parameters of the patients may be diluted due to the fluid therapy applied in the post-operative period. We also concluded that NLR was not affected by fluid therapy and might be a valuable parameter in monitoring infection after appendectomy. Moreover, platelet markers such as PDW, MPW and platelet count are not useful parameters in the diagnosis of AA. Further studies with larger patient groups are now needed to support our findings.

\section{Ethics}

Ethics Committee Approval: Approval of the local ethics committee of Ankara Training and Research Hopital (approval no: $13122017 / 0028.311)$.

Informed Consent: Informed consent form was obtained from all patients included in this study.

Peer-review: Externally peer-reviewed.

\section{Authorship Contributions}

Surgical and Medical Practices: B.K., Concept: A.S.Y., Design: T.E., Data Collection or Processing: T.E., Analysis or Interpretation: B.K., Literature Search: A.S.Y., Writing: B.K.

Conflict of Interest: The authors declare that they have no conflicts of interest.

Financial Disclosure: There are no financial support for this study.

\section{REFERENCES}

1. Bachmann LM, Bischof DB, Bischofberger SA, Bonani MG, Osann FM, Steurer J. Systematic quantitative overviews of the literature to determine the value of diagnostic tests for predicting acute appendicitis: study protocol. BMC Surg 2002;2:2. 
2. Omundsen M, Dennett E. Delay to appendicectomy and associated morbidity: a retrospective review. ANZ J Surg 2006;76:153-5.

3. Lee SL, Ho HS. Acute appendicitis: is there a difference between children and adults? Am Surg 2006;72:409-13.

4. Kaykısız EK. (19-22 Nisan 2018). Bilinen Bir Tanının Az Bilinen Prezentasyonu: Akut Kolesistiti Taklit Eden Bir Akut Apandisit Vakası. B. Cander Editörler, 14. Ulusal Acil Tıp Kongresi (94), Antalya, Acil Tıp Uzmanları Derneği.

5. Choi SB, Han HJ, Kim WB, Song TJ, Choi SY. A case of a recurrent iliopsoas abscess masking a complicated appendicitis successfully treated by a laparoscopic approach. Surg Laparosc Endosc Percutan Tech 2010;20:e6972.

6. Kuday Kaykisiz E, Yildirim MB, Dadali E, Kaykisiz H, Ünlüer EE. Different manifestation of a familiar diagnosis: From anuria to acute appendicitis. Am J Emerg Med 2018;36:910.e5-910.e7.

7. Kaykısız EK, Akyol PY, Karakaya Z, Payza U, Topal FE. Neutrophil/lymphocyte ratio is a valuable data to reduce negative laparotomy rates in emergency department. Bio Med Res 2017;28:8438-42.

8. Börekçi H, Karacabey S, Sipahi M, Özdemir ZT, Erkoç MF. A rare case: Retrocecal appendicitis adherent to the liver capsule. Turk J Surg 2015;33:227-9.

9. Yardımcı S, Uğurlu MÜ, Coșkun M, Attaallah W, Yeğen ŞC. Neutrophillymphocyte ratio and mean platelet volume can be a predictor for severity of acute appendicitis. Ulus Travma Acil Cerrahi Derg 2016;22:163-8.

10. Bozkurt S, Köse A, Erdogan S, Bozali Gl, Ayrik C, Arpaci RB, et al. MPV and other inflammatory markers in diagnosing acute appendicitis. J Pak Med Assoc 2015;65:637-41.

11. Yiğitler C, Uyar C, Baylan O, Ongörü O, Güleç B, Akut apandisit ön tanısıyla ameliyat edilen hastalarda C-reaktif proteinin tanısal değeri ve postoperatif doğal seyri. Turk j surg 2002;8: 224-33.

12. Daskalakis K, Juhlin C, Påhlman L. The use of pre- or postoperative antibiotics in surgery for appendicitis: a systematic review. Scand J Surg 2014; $103: 14-20$

13. Albayrak Y, Albayrak A, Albayrak F, Yildirim R, Aylu B, Uyanik A, et al. Mean platelet volume: a new predictor in confirming acute appendicitis diagnosis. Clin Appl Thromb Hemost 2011;17:362-6.
14. Narci H, Turk E, Karagulle E, Togan T, Karabulut K. The role of mean platelet volume in the diagnosis of acute appendicitis: a retrospective casecontrolled study. Iran Red Crescent Med J 2013 ;15:e11934.

15. Kılıç TY, Yesilaras M, Karaali C, Atilla OD, Sezik S. Diagnostic value of mean platelet volume in acute appendicitis. J Clin Anal Med 2015;1-3.

16. Aktimur R, Cetinkunar S, Yildirim K, Özdas S, Aktimur SD, Mean platelet volume is a significant biomarker in the differential diagnosis of acute appendicitis. Inf Cell Sig 2015;2:e930.

17. Fan Z, Pan J, Zhang Y, Wang Z, Zhu M, Yang B, et al. Mean platelet volume and platelet distribution width as markers in the diagnosis of acute gangrenous appendicitis. Dis Markers 2015;2015:542013.

18. Tanrikulu CS, Tanrikulu Y, Sabuncuoglu MZ, Karamercan MA, Akkapulu N, Coskun F. Mean platelet volume and red cell distribution width as a diagnostic marker in acute appendicitis. Iran Red Crescent Med J 2014;16:e10211.

19. Bilici S, Sekmenli T, Göksu M, Melek M, Avci V. Mean platelet volume in diagnosis of acute appendicitis in children. Afr Health Sci 2011;11:427-32.

20. Uyanik B, Kavalci C, Arslan ED, Yilmaz F, Aslan O, Dede S, et al. Role of mean platelet volume in diagnosis of childhood acute appendicitis. Emerg Med Int 2012;2012:823095.

21. Dinc B, Oskay A, Dinc SE, Bas B, Tekin S. New parameter in diagnosis of acute appendicitis: platelet distribution width. World J Gastroenterol 2015;21:1821-6

22. Yılmaz Y, Kara F, Gümüşdere M, Arslan H, Üstebay S. The platelet indices in pediatric patients with acute appendicitis. Int J Res Med Sci 2015;3:1388-91.

23. Wullstein C, Barkhausen S, Gross E. Results of laparoscopic versus conventional appendectomy in complicated appendicitis. Dis Colon Rectum 2001:44:1700-5.

24. Lin HF, Wu JM, Tseng LM, Chen KH, Huang SH, Lai IR. Laparoscopic versus open appendectomy for perforated appendicitis. J Gastrointest Surg 2006;10:906-10. 